\title{
PEMBERDAYAAN DAN PEMANFAATAN TOGA DALAM MENINGKATKAN SISTEM IMUN PADA MASA PANDEMI COVID-19 DI KELURAHAN NUSANTARA PERMAI
}

\author{
Rasmi Zakiah Oktarlina ${ }^{1}$, Afra Rahmania Santi ${ }^{2}$ \\ ${ }^{1}$ Farmasi, Fakultas Kedokteran, Universitas Lampung \\ ${ }^{2}$ Akuntansi, Fakultas Ekonomi dan Bisnis, Universitas Lampung, Bandar Lampung \\ Penulis Korespodensi : rasmizakiahoktarlina@gmail.com
}

\begin{abstract}
Abstrak
Covid-19 merupakan penyakit yang sedang menjadi pandemi di berbagai belahan dunia karena laju penyebarannya yang sangat cepat. Untuk mengatasi covid-19 perlu adanya upaya pencegahan, salah satunya dengan meningkatkan imunitas tubuh dengan penggunaan tanaman obat keluarga. Penggunaan Tanaman obat dan keluarga didasari oleh efek khasiatnya sebagai obat yang dipergunakan untuk penyembuhan maupun mencegah berbagai penyakit dan memiliki kandungan efek sinergi dari berbagai zat yang mempunyai efek mengobati. Atas dasar-dasar tersebut maka dilakukan pengabdian pembuatan kebun tanaman obat dan keluarga yang dapat dilakukan dalam rangkaian proses Kuliah Kerja Nyata $(\mathrm{KKN})$. Kegiatan ini penting dilakukan agar masyarakat mengetahui dan memanfaatkan tanamantanaman obat yang ada disekitar untuk mengobati penyakit-penyakit tertentu sebelum memutuskan untuk melakukan pengobatan medis yang menggunakan obatkimia. Sehingga masyarakat dimasa pandemi covid-19 mampu menyediakan obat yang lebih murah dan efeksamping yang lebih ringan. Metode yang digunakan adalah penyuluhan dan praktik atau demonstrasi. Sehingga masyarakat dapat mempraktikkan secara langsung dan menerapkan di sekitar lingkungan rumah. Dalam pelaksanaannya disampaikan metode pengolahan tanaman TOGA sehingga menjadi minuman immunostimulan yang menyehatkan maupun bagaimana cara menanamnya. Hasil yang diperoleh ialah terdapat peningkatan kemampuan dan kesadaran masyarakat yang mulai menanam tanaman obat dan keluarga dipekarangan rumahnya.
\end{abstract}

Kata kunci: pandemi covid-19, Penanaman, Pembuatan Tanaman Obat Keluarga

\begin{abstract}
Covid-19 is a disease that is becoming a pandemic in various parts of the world because of its very fast spread rate. To overcome covid-19, prevention efforts are needed, one of which can be by increasing the body's immunity with the use of medicinal plants and their families. The use of medicinal plants and their families is based on their medicinal effects as drugs that are used to cure and prevent various diseases, and have a synergistic effect of various substances that have a medicinal effect. Based on these basics, I made a medicinal plant garden and family dedication which I can do in a series of real work lectures processes $(K K N)$. This activity is important to do so that people know and utilize medicinal plants around them to treat certain diseases before deciding to undertake medical treatment using chemical drugs. So that people during the Covid-19 pandemic are able to provide cheaper drugs and lighter side effects. The method used is counseling and practice or demonstration. So that people can practice directly and apply in their homes. In its implementation, the TOGA plant processing method is conveyed so that it becomes a healthy immunostimulant drink and how to plant it. The results obtained are that there is an increase in the ability and awareness of people who have started planting medicinal plants and their families in their yards.
\end{abstract}

Keywords: Covid-19 pandemic, Planting, Making Family Medicinal Plants 


\section{Jurnal Pengabdian Kepada Masyarakat BUGUH}

Dipublikasikan

Badan Pelaksana Kuliah Kerja Nyata

Universitas Lampung

Sekretariat Badan Pelaksana Kuliah Kerja Nyata, Universitas Lampung

Jl. Prof. Dr. Soemantri Brojonegoro No. 1, Bandar Lampung 35145.

\section{Pendahuluan}

Kuliah Kerja Nyata (KKN) merupakan salah satu aktivitas perkuliahan dalam bentuk pengabdian pada masyarakat dan secara langsung mengidentifikasi serta menangani masalah-masalah pembangunan yang dihadapi dalam desa baik secara induvidual maupun secara umum. KKN Tematik merupakan proses pembelajaran bagi mahasiswa sekaligus wahana pemberdayaan masyarakat. Pola ini direncanakan dan dilaksanakan secara sistematis berdasarkan tema yang digali dari potensi masyarakat, dirumuskan, dan dilaksanakan bersama masyarakat. Hal ini diharapkan dapat memacu kemampuan masyarakat dalam pengembangan diri dan wilayah, sehingga kesejahteraannya meningkat.KKN merupakan proses pembelajaran bagi mahasiswa sekaligus wahana pemberdayaan masyarakat. Pola ini direncanakan dan dilaksanakan secara sistematis berdasarkan potensi dan masalah yang dihadapi masyarakat, dirumuskan dan dilakukan bersama masyarakat. Hal ini diharapkan dapat memacu kemampuan masyarakat dalam pengembangan diri dan wilayah, sehingga kesejahteraanya meningkat.

Kelurahan Nusantara Permai merupakan salah satu kelurahan dari tujuh kelurahan yang berada di Kecamatan Sukabumi,Kota Bandar Lampung. Awalnya Kelurahan ini merupakan komplek Perumahan yang bernama Perumahan Nusantara Permai, yang di bangun oleh Pengembang Arya Mandala Dwipa (AMD) yang dimulai pada tahun 1997 an. Mengingat perkembangan jumlah penduduk yang demikian pesat akhirnya Perumahan Nusantara Permai menjadi Kelurahan sendiri menginduk ke Kecamatan Sukabumi. Kelurahan Nusantara permai memiliki luas wilayah \pm 70 Hektar yang dibagi menjadi 3 Lingkungan dan 9 RT. Kelurahan Nusantara Permai berjarak $1 \mathrm{Km}$ dari pusat pemerintahan Kecamatan Sukabumi, berjarak $8 \mathrm{Km}$ dari pusat pemerintahan Kota Bandar Lampung dan berjarak $10 \mathrm{Km}$ dari pusat pemerintahan Provinsi Lampung. Berdasarkan data monografi, Kelurahan Nusantara Permai memiliki penduduk sebanyak 4567 jiwa, yang terdiri dari $1069 \mathrm{KK}$, yang terdiri dari 2454 laki-laki dan 2013 perempuan. Tingkat pendidikan rata-rata penduduk sedang dan sudah menempuh serta menyelesaikan masa wajib belajar 12 tahun untuk anak-anak dan dewasa, sedangkan orang tua dan usia lanjut kebanyakan menepuh pendidikan SLTA/Sederajat saja.

Covid-19 merupakan penyakit yang disebabkan oleh infeksi virus SARS CoV 2 (Onchongo et al., 2020). Covid-19 sedang menjadi pandemi dalam kurun waktu ini di berbagai belahan dunia, hal tersebut dikarenakan kemampuannya yang cepat dalam menginfeksi penderita sehingga penyebarannya pun dengan cepat meluas. Pandemi Covid-19 telah ditetapkan menjadi kedaruratan Kesehatan Masyarakat secara Global (Global Public Health Emergency) oleh Badan Kesehatan Dunia (WHO) pada 30 Januari 2020 yang lalu (Sohrabi et al,. 2020). Menurut WHO, setidaknya ada 199 negara dan teritori yang telah terpapar virus yang pertama kali muncul di Wuhan, China (World Health Organization, 2020). Indonesia sendiri menetapkan infeksi SARS COV 2 menjadi bencana nasional pada tanggal 13 April 2020 (Keputusan Presiden Republik Indonesia, 2020). Di Indonesia kasus yang terkonfirmasi positif covid 19 yaitu berjumlah 1.682.004 orang positif terinfeksi Covid-19. Dari total tersebut, 1.535.491 di antaranya sudah sembuh. Sementara itu, 45.949 orang meninggal dunia dan 100.564 masih menjalani perawatan atau isolasi karena terjangkit Covid-19. Tercatat ada juga 75.355 orang berstatus suspek Covid-19 (Kemenkes, 2021). Kasus Covid-19 telah menyebar di seluruh provinsi Indonesia, dari Aceh hingga Papua.Secara rinci, sudah 510 kabupaten/kota di 34 provinsi yang mencatat penularan virus corona. Ini berarti pandemi sudah berdampak ke lebih dari 99 persen wilayah Indonesia. Oleh karena itu dalam mencegah penyebarannya, masyarakat dihimbau untuk selalu menjaga agar tidak tertular, diantaranya dengan mencuci tangan dengan benar, menggunakan masker, membatasi aktivitas di luar rumah, menghindari kerumunan, melakukan social distancing diikuti dengan proses belajar, bekerja, dan beribadah di rumah serta melakukan disinfeksi benda/permukaan yang diduga terinfeksi oleh virus corona. Maka untuk mencegah penularan dan penyebarannya adalah dengan senantiasa menjaga kebersihan dari diri dan lingkungan.

Tanaman Obat Keluarga (TOGA) pada hakekatnya adalah tanaman berkhasiat yang ditanam di lahan pekarangan yang dikelola oleh keluarga. Ditanam dalam rangka memenuhi keperluan keluarga akan obatobatan tradisional yang dapat dibuat sendiri (Kementan, 2015). Penanaman TOGA dapat di pot atau di 


\section{Jurnal Pengabdian Kepada Masyarakat BUGUH}

Dipublikasikan

Badan Pelaksana Kuliah Kerja Nyata

Universitas Lampung

Sekretariat Badan Pelaksana Kuliah Kerja Nyata, Universitas Lampung

Jl. Prof. Dr. Soemantri Brojonegoro No. 1, Bandar Lampung 35145.

lahan sekitar rumah, dan jika lahan yang ditanami cukup luas maka sebagian hasil panen dapat dijual dan menambah pendapatan keluarga (Permatasari, 2019). Bagian dari tumbuhan yang dapat dimanfaatkan sebagai obat adalah bagian daun, kulit batang, buah, biji dan akarnya (Harjono, 2017). Manfaat TOGA selain sebagai obat juga memiliki beberapa manfaat lain yaitu sebagai penambah gizi, bumbu atau bahan rempah-rempah masakan dan dapat menambah keindahan (Patola, 2018). Keberadaan TOGA juga berfungsi sebagai upaya pelestarian tanaman obat dari proses pelangkaan (Dinkes Kediri, 2017).

Tumbuhan obat dan obat tradisional sejak zaman dahulu memainkan peranan penting dalam menjaga kesehatan, mempertahankan stamina dan mengobati penyakit. Oleh karena itu tumbuhan obat dan obat tradisional telah berakar kuat dalam kehidupan sebagian masyarakat hingga saat ini (Hikmat, 2011).

Tanaman obat keluarga (TOGA) menjadi salah satu pilihan masyarakat untuk ditanam di lahan pekarangan, dengan pertimbangan karena dapat dimanfaatkan untuk kesehatan. Tanaman obat dapat dijadikan obat yang aman, tidak mengandung bahan kimia, murah, dan mudah didapat (Kementan, 2015).Dalam rangka memperdayakan dan mendorong peran aktif masyarakat dalam upaya pengembangan kesehatan tradisional perlu mengarahkan agar masyarakat dapat melakukan perawatan kesehatan secara mandiri dan benar melalui pemanfaatan tanaman obat sebagai obat tradisional berupa jamu, Obat Herbal Terstandar (OHT), dan fitofarmaka. Dan pemanfaatan obat tradisional tersebut sebagai upaya untuk pemeliharaan kesehatan, pencegahan penyakit dan perawatan kesehatan termaksud pada masa kedaruratan kesehatan masyarakat.

Pemerintah juga menghimbau seluruh masyarakat untuk meningkatkan imunitas tubuh agar terhindar dari infeksi COVID-19. Imunitas tubuh dapat ditingkatkan dengan menerapkan prilaku pola hidup sehat. Pola hidup sehat meliputi pola makan dengan asupan nutrisi yang seimbang, dan olahraga. Nutrisi tambahan dapat berupa mengkonsumsi rempah-rempah.Peningkatan imunitas dapat dilakukan dengan menggunakan berbagai ramuan tradisional yang dikenal dengan istilah jamu. Potensi peningkatan imunitas dari olahan jamu dapat diperoleh dari tanaman obat keluarga atau yang dikenal dengan istilah TOGA. Program yang dapat dilakukan masyarakat dalam rangka peningkatan kesehatan dengan mengelola lingkungan sekitarnya. Tidak hanya untuk tanaman obat, tapi juga untuk tanaman hias, bunga atau buah-buahan. Tanaman ini nantinya dapat diolah menjadi jamu. Mulai jamu dalam bentuk cairan dan langsung minum atau dikemas dalam bentuk bubuk. Jamu adalah ramuan unik untuk pengobatan herbal di Indonesia dan digunakan untuk mengobati apapun sesuai dengan efektifitas tanaman yang dikenal secara turun-temurun Inilah yang dimaksud mempunyai manfaat ganda, karena hasilnya dapat memberikan banyak manfaat.

Selama ini, masyarakat hanya tahu menanam, namun tidak tahu menggunakannnya, selain itu kalau ada keluarga mereka sakit lebih memilih kerumah sakit dan menggunakan obat-obat kimia, padahal disekiling kita ada berbagai jenis tanaman obat yang bisa dimanfaatkan.Halaman rumah tampak menghijau disesaki berbagai jenis tanaman hias dan obat-obatan yang tertata rapi (Tilaar, 1998).Tanaman obat banyak digunakan sebagai bahan baku obat tradisional dan jamu, yang apabila dikonsumsi dapat meningkatkan kekebalan tubuh (immune system), karena tanaman ini mempunyai sifat spesifik sebagai tanaman obat yang bersifat pencegahan (preventif) dan promotif melalui kandungan metabolit sekunder contohnya seperti gingiro pada jahe dan santoriso pada temulawak yang mampu meningkatkan sistem kekebalan tubuh. Jamu tidak dapat menyembuhkan yaitu bersifat kuratif, namun lebih ke arah sebagai pencegahan dengan cara meningkatkan kekebalan tubuh, sehingga lebih bermanfaat untuk mencegah COVID-19.

Salah satunya mencegah penyakit yang disebabkan virus corona, selain membatasi penyebaran virusnya, adalah dengan meningkatkan sistem imun atau daya tahan tubuh. Pola hidup sehat, seperti cukup waktu istirahat, olah raga rutin dan konsumsi makanan bergizi dan seimbang, dapat mempertahankan dan meningkatkan imunitas tubuh. sistem imun dalam tubuh dapat ditingkatkan salah satunya dengan cara menggunakan imunostimulan yang berfungsi untuk meningkatkan pertahanan alami tubuh dalam mengatasi infeksi virus ataupun bakteri (Amalia dan Hiola, 2020). Jamu ataupun produk alami dari tanaman obat dapat menjadi pilihan imunostimulan yang mudah didapat dan diolah, terutama jika keluarga memiliki tanaman obat keluarga (TOGA) (Pertiwi et al., 2020). 


\section{Jurnal Pengabdian Kepada Masyarakat BUGUH}

Dipublikasikan

Badan Pelaksana Kuliah Kerja Nyata

Universitas Lampung

Sekretariat Badan Pelaksana Kuliah Kerja Nyata, Universitas Lampung

Jl. Prof. Dr. Soemantri Brojonegoro No. 1, Bandar Lampung 35145.

Tanaman Obat Keluarga (TOGA), merupakan salah satu program yang dapat dilaksanakan oleh masyarakat dalam upaya peningkatan kesejahteraan dan kesehatan di rumah tangga, khususnya di bidang pangan. Program ini sekaligus menyikapi menurunnya daya beli masyarakat akibat harga obat yang semakin mahal dan terjadi kenaikan harga obat herbal di masa pandemi Covid-19, sehingga secara tidak langsung berdampak pada menurunnya derajat kesehatan masyarakat. TOGA adalah tanaman hasil budidaya rumahan yang berkhasiat sebagai obat. Penanaman TOGA dapat di pot atau di lahan sekitar rumah, dan jika lahan yang ditanami cukup luas maka sebagian hasil panen dapat dijual dan menambah pendapatan keluarga. Adapun pemanfaatan TOGA selain sebagai obat, juga dapat dimanfaatkan untuk penambah gizi keluarga,bumbu atau rempah-rempah dan menambah keindahan .

Tumbuhan dalam toga yang dapat digunakan sebagai imunostimulan diantaranya adalah kunyit, jahe dan lengkuas yang dapat dibuat menjadi minuman imunostimulan. Kunyit (Curcuma longa L.) merupakan rimpang yang banyak ditanam di Indonesia yang mengandung kurkumin berkhasiat sebagai antiinflamasi, antikanker dan meningkatkan imun tubuh. Selain kunyit, beberapa tumbuhan lain yang mempunyai manfaat imunostimulan adalah jahe (kandungan gingiro) dan temulawak (kandungan santoriso). Konsumsi rimpang dan tumbuhan tersebut dapat dibuat dengan cara menyeduh dengan air panas menjadi sediaan minuman (Meilina et al., 2020).

Permasalah yang terjadi di Kelurahan nusantara Permai yaitu pada umumnya masyarakat di wilayah tersebut kurang memiliki pemahaman pemanfaatan lahan pekarangan yang cukup luas, sehingga pemanfaatan dan pengelolaan lingkungan dapat dioptimalkan dengan memberikan pelatihan penanaman TOGA baik di lahan pekarangan maupun media polybag. Berdasarkan observasi di lapangan diketahui bahwa beberapa ibu rumah tangga telah menanam TOGA, namun demikian jumlah TOGA yang ditanam jumlahnya terbatas. Selain hal tersebut, masalah yang ada di Kelurahan Nusantara Permai adalah menurunnya daya beli masyarakat akibat harga obat yang semakin mahal dan beberapa rempah herbal juga mengalami kenaikan harga di masa pandemi ini, sehingga secara tidak langsung berdampak pada menurunnya derajat kesehatan masyarakat. TOGA adalah tanaman hasil budidaya rumahan yang berkhasiat sebagai obat, sehingga masyarakat bisa memanfaatkan khasiat tanaman TOGA apabila sakit. Hal tersebut dapat meminimalkan biaya berobat yang relativ lebih mahal. Masyarakat yang telah memiliki pengetahuan tentang khasiat TOGA dan menguasai cara pengolahannya dapat membudidayakan tanaman obat secara individual dan memanfaatkannya sehingga akan terwujud prinsip kemandirian dalam pengobatan keluarga.

Selain itu juga dapat dikembangkan menjadi usaha usaha industi rumah tangga di bidang obat-obatan herbal, yang selanjutnya dapat disalurkan ke masyarakat. Mengingat TOGA sangat bermanfaat untuk kesehatan, maka adanya pemanfaatan sumberdaya perdesaan berupa TOGA dengan melibatkan masyarakat RT 06 Kelurahan Nusantara Permai diharapkan mampu mendukung peningkatan kesehatan.

\section{Bahan dan Metode}

Metode yang dilaksanakan pada pengabdian ini ialah penyuluhan dan praktik yang dilakukan secara tatap muka atau luring. Kegiatan ini berlangsung dengan memperhatikan protokol kesehatan seperti menggunakan masker dan peserta yang dibatasi yakni maksimal lima orang, sesuai dengan anjuran yang diberi oleh institusi. Sasaran dalam kegiatan ini ialah warga RT 06 Kelurahan nusantara Permai, Kecamatan Sukabumi. Berikut Ringkasan metode pelaksanaan beserta jam kerja efektif mahasiswa (JKEM) tersaji pada Tabel I. 


\section{Jurnal Pengabdian Kepada Masyarakat BUGUH}

Dipublikasikan

Badan Pelaksana Kuliah Kerja Nyata

Universitas Lampung

Sekretariat Badan Pelaksana Kuliah Kerja Nyata, Universitas Lampung.

Jl. Prof. Dr. Soemantri Brojonegoro No. 1, Bandar Lampung 35145.

Tabel I. Metode, Kegiatan, JKEM dan keterlibatan mahasiswa

\begin{tabular}{|l|l|l|l|l|l|}
\hline No & \multicolumn{1}{|c|}{ Metode } & \multicolumn{1}{|c|}{ Kegiatan } & JKEM & $\begin{array}{c}\text { Jumlah } \\
\text { Mahasiswa } \\
\text { yang terlibat }\end{array}$ \\
\hline 1 & $\begin{array}{l}\text { Pendidikan } \\
\text { Masyarakat }\end{array}$ & $\begin{array}{l}\text { Pemberian materi penyuluhan, } \\
\text { pada tahap ini peserta diberikan } \\
\text { materi dengan metode ceramah } \\
\text { pada warga RT 06 Nusantara } \\
\text { Permai tentang edukasi } \\
\text { pemanfaatan tanaman obat } \\
\text { keluarga penting dilakukan }\end{array}$ & $\begin{array}{l}1 \times 100 \\
\text { menit }\end{array}$ & $\begin{array}{l}\text { Semua } \\
\text { anggota } \\
\text { KKN } \\
\text { Nusantara } \\
\text { Perai }\end{array}$ \\
\hline 2. & Praktek & $\begin{array}{l}\text { Pembuatan kebun TOGA di } \\
\text { lahan kosong RT 06 dan } \\
\text { pelaksanaan penanaman } \\
\text { TOGA diikuti oleh beberapa } \\
\text { warga RT 06 }\end{array}$ & & mx100 \\
menit & $\begin{array}{l}\text { Semua } \\
\text { anggota } \\
\text { KKN } \\
\text { Nusantara } \\
\text { Perai }\end{array}$ \\
\hline
\end{tabular}

\section{Hasil dan Pembahasan}

Kegiatan penyuluhan dan pembuatan kebun TOGA dilaksanakan pada Senin 15 Februari 2020 sampai hari Jum'at 19 Februari 2020 dengan melibatkan masyarakat sebagai peserta dan mahasiswa sebagai pelaksana atau pemateri. Secara keseluruhan kegiatan penyuluhan dan pembuatan kebun TOGA berlangsung dengan baik, peserta merespon kegiatan secara positif dan mengikuti serangkaian kegiatan dengan seksama. Hasil yang dicapai yaitu tanaman obat yang sudah di tanam sudah mulai tumbuh, terlihat pada tanaman kunyit, jahe,kencur, lidah buaya,lavender,kumis kucing dll. Penanaman tanaman obat ini diikuti dengan penempelan papan nama disertai dengan manfaat setiap jenis tanaman obat tersebut. Tindak lanjutnya, pelaksana kegiatan ini mengharapkan bahwa warga Nusantara Permai dapat menjadikan kebun tanaman obat (TOGA) sebagai obat herbal dalam kehidupan sehari-hari.

Agar bisa terhindar dari virus covid-19 ini adalah dengan memiliki imunitas tubuh yang baik.Virus Corona ini yang diserangnya adalah imunitas tubuh kita, jika imunitas kita rendah, maka virus tersebut akan cepat menyebar di dalam tubuh, namun jika imunitas kita bagus, maka virus tadi tidak bisa berkembang,sehingga salah satu upaya untuk meningkatkan imunitas tubuh adalah dengan meminum minuman kesehatan yang berasal dari rempah-rempah, sehingga akhirnya membuat kebun taman Toga yang berisikan tanaman rimpang seperti jahe, kunyit, kencur, temulawak dan kumis kucing.Tanaman Toga ini dapat digunakan dalam pembuatan minuman kesehatan yang berguna dalam meningkatkan imun tubuh dalam rangka pencegahan Covid-19 selain social distancing, cuci tangan, dan penggunaan masker.

Kegiatan ini diawali dengan proses persiapan lahan yang harus dilakukan karena ini juga menentukan keberhasilan pembuatan kebun tanaman obat keluarga. Persiapan lahan ini dapat berupa survey lapangan dimana tanaman akan ditanam, melihat kondisi lahan yang diberi izin untuk dilakukan pembuatan kebun. Kegiatan selanjutnya penyuluhan terkait edukasi pemanfaatan tanaman obat keluarga yang berlangsung pada tanggal 16 Februari 2021 yang dilakukan karena masyarakat Nusantara Permai pada umumnya memanfaatkan pekarangan untuk ditanami bunga yang hanya memiliki nilai estetika bahkan banyak pula yang hanya dibiarkan begitu saja. Oleh karena itu, mahasiswa KKN mengadakan program pemanfaatan pekarangan rumah dengan menggalakan ibu-ibu rumah tangga untuk menanam tanaman obat di pekarangan rumah. Dengan banyaknya khasiat yang ditawarkan oleh TOGA diharapkan masyarakat dapat memperoleh manfaatnya sehingga dapat menuju masyarakat Indonesia yang sehat. Dalam kegiatan ini, warga RT06 diberikan materi tentang manfaat dan khasiat tanaman obat .Selama pemberian materi, ibu-ibu antusias dalam diskusi mengenai materi yang telah disampaikan.Dengan adanya kebun TOGA di lingkungan rumah 


\section{Jurnal Pengabdian Kepada Masyarakat BUGUH}

Dipublikasikan

Badan Pelaksana Kuliah Kerja Nyata

Universitas Lampung

Sekretariat Badan Pelaksana Kuliah Kerja Nyata, Universitas Lampung

Jl. Prof. Dr. Soemantri Brojonegoro No. 1, Bandar Lampung 35145.

selain jadi semakin hijau dan asri, kalau ada yang sakit tanamannya juga bisa dimanfaatin untuk obat. Kegiatan ini dilakukan atas Kurangnya pemahaman masyarakat Kelurahan Nusantara Permai dalam memanfaatkan lahan pekarangan dan adanya lahan kosong yang dapat dimanfaatkan untuk ditanami tanaman obat dan kurangnya kesadaran pentingnya tanaman obat keluarga sebagai kebutuhan keluarga untuk kehidupan sehari-hari terlebih dalam meningkatkan imunitas tubuh.

Pada tanggal 17 Februari dilakukan pembersihan lahan dari rumput liar dan melakukan penggemburan tanah. Selanjutnya pada 18 Februari dilakukannya penanaman toga (Tanaman Obat Keluarga) yang berlangsung mulai pukul 09.00 sampai 16.00 WIB yang berlokasi di lahan kosong RT 06, Kelurahan Nusantara Permai, kegiatan ini berlangsung dengan penuh antusias oleh mahasiswa KKN UNILA dan ibuibu sekitar RT 06 . Teknis kegiatan ini dilakukan yaitu pada kegiatan Penanaman TOGA (Taman Obat Keluarga) dilakukan dengan cara menyiapkan media tanam menggunakan pupuk arang sekam dan dilakukan penggemburan tanah diarea lahan. Tanaman obat keluarga yang ditanam meliputi (Jahe, kunyit, lidah buaya, Sereh, lengkuas, Kencur, lavender, dll) dan kegiatan Penanaman TOGA (Taman Obat Keluarga). Penanaman ini cukup lama karena perlu membersihkan lahan dari rumput liar dan sampah serta penggemburan tanah dan penebaran pupuk di area lahan. Media tanam yang digunakan yaitu dengan menggunakan media tanah dan arang sekam dengan menggunakan perbandingan 1:1. Setelah selesai dengan media tanam dilanjutkan dengan menanam tanaman obat yang telah disiapkan, kemudian dilakukan penyiraman sebanyak satu kali perhari nya. Selanjutnya Pada 19 Februari dilakukan penandaan lahan dengan menggunakan jaring yang mengelilingi area lahan dan penyerahan hasil pembuatan Kebun TOGA kepada Ibu RT 06 Nusantara Permai.

Faktor Pendukung :

1. Adanya dukungan dari warga sekitar, pamong kelurahan Nusantara Permai dan masyarakat untuk menjalankan kegiatan ini.

2. Adanya dukungan dan bantuan dari sesama teman KKN

3. Adanya lahan sehingga sangat mudah untuk melakukan pembuatan kebun tanamanan obat

Faktor Penghambat :

Kendala yang dihadapi dalam melaksanakan program ini yaitu sulitnya pengemburan tanah dikarenakan lahan kosong tersebut terdapat batuan semen yang menutupi area penanaman BUNTOgA Tanah yang digunakan sebagai lahan tanaman obat tidak begitu subur, sehingga diperlukan pemupukan terlebih dulu agar tanaman obat dapat tumbuh dengan baik. Namun terkait dengan perizinan semua dapat teratasi dengan baik.

Dengan demikian kegiatan pengabdian masyarakat yang di lakukan oleh mahasiswa KKN telah sesuai dengan kebutuhan mayarakat Kelurahan Nusantara Permai, Kecamatan Sukabumi, Kota Bandar Lampung, kerja sama mulai dibangun dan bisa diterima oleh masyakarakat. Dalam hal ini dapat memunculkan aspek peningkatan imunitas tubuh dan meningkatkan motivasi masyarakat untuk mulai menanam tumbuhan obat di pekarangan rumahnya. Untuk komunikasi dengan masyarakat awalnya kurang lancar karna pengabdi hanya mengenal pamong saja, namun tindak lanjunya menjadi lebih baik. Hal ini dapat di lihat dari kegiatan pengabdian dapat mendorong kemandirian masyarakat dan kegiatan pengabdian yang dirasakan bermanfaat bagi masyarakat dengan waktu pelaksanaan yang begitu singkat. 


\section{Jurnal Pengabdian Kepada Masyarakat BUGUH}

Dipublikasikan

Badan Pelaksana Kuliah Kerja Nyata

Universitas Lampung

Sekretariat Badan Pelaksana Kuliah Kerja Nyata, Universitas Lampung Jl. Prof. Dr. Soemantri Brojonegoro No. 1, Bandar Lampung 35145.

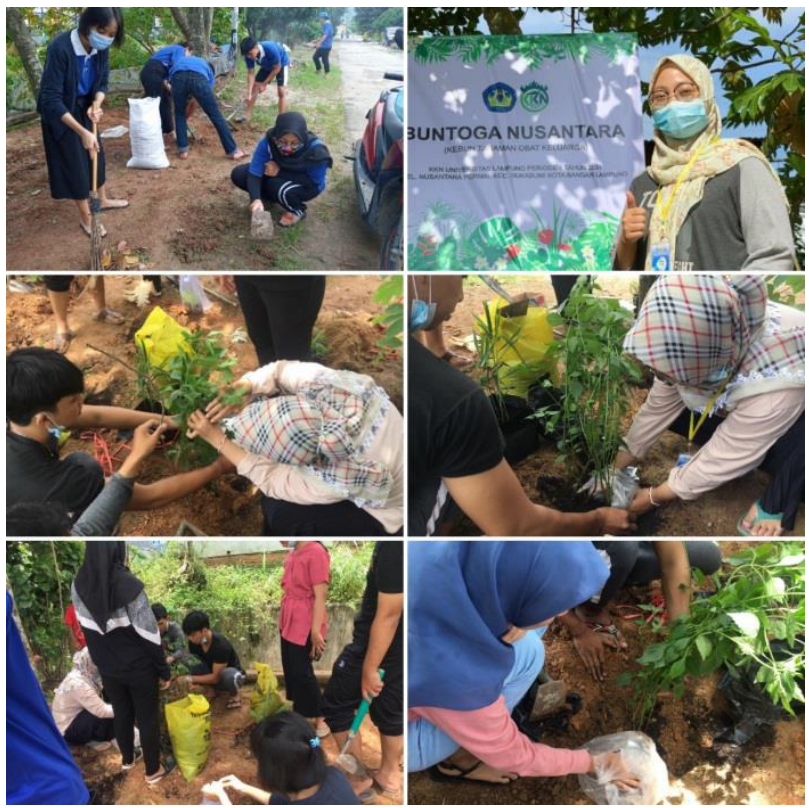

Gambar 1 Gambar Pelaksanaan KKN

Indikator keberhasilan produk ditandai dengan : (1) Kemampuan pengetahuan dan kesadaran yang meningkat dari para warga dan para mahasiswa KKN setelah melaksanakan penyuluhan edukasi tanaman obat. (2) Pembuatan dan pelestarian kebun tanaman obat yang dilakukan bersama warga Nusantara Permai dan mahasiswa KKN. (3) Tersediannya lahan sebagai pengembangan tanaman obat bisa di manfaatkan warga sekitar.

\section{Kesimpulan}

Dengan melakukan penanaman TOGA (Tanaman Obat Keluarga) diharapkan masyarakat Kelurahan Nusantara Permai bisa selalu memanfaatkan lahan pekarangan kosong yang ada dengan melakaukan penaman TOGA tersebut yang meliputi (jahe, kunyit, kencur, lengkuas, temulawak dan sereh) yang dimana tanman tersebut bisa memenuhi keperluan pangan dapur keluarga dan meningkatan imunitas tubuh selama pandemi ini.

\section{Daftar Pustaka}

Amalia L, Hiola I F. 2020. Analisis gejala klinis dan peningkatan kekebalan tubuh untuk mencegah penyakit covid-19. Jambura jurnal of Health Sciences and Research, 2(2):71 -76

Athena, A., Laelasari, E., \& Puspita, T. (2020). Pelaksanaan Disinfeksi Dalam Pencegahan Penularan Covid-19 Dan Potensi Risiko Terhadap Kesehatan Di Indonesia. Jurnal Ekologi Kesehatan, 19(1), 120.

Churaez, F. I., Ramadani, R., Firmansyah, R., Mahmudah, S. N., \& Ramli, S. W (2020). Pembuatan Dan Pemanfaatan Tanaman Obat: Kegiatan Kkn Edisi Covid-19 Di Desa Itolungan, Gorontalo. Sinergi: Jurnal Pengabdian, 2(2), 40-45.

Keputusan Presiden Republik Indonesia No 12 tahun 2020 tentang Penetapan Bencana Non Alam Penyebaran Corona Virus Disease (COVID 19) sebagai bencana nasional

Mama, R. 2020. "5 Tanaman Obat Keluarga (TOGA) yang Dipercaya Bisa Cegah Virus Corona". dikutip dari https://kumparan.com/5-tanaman-obat-keluarga-toga-yang-dipercaya-bisa-cegah-virus-corona 1swLLCcrrOU/full .Diakses tanggal 27 Februari 2021.

Riyandhi, A. 2020. "Mahasiswa Unimal Kembangkan TOGA Untuk Minuman Kesehatan". dikutip dari https://news.unimal.ac.id/index/single/1149/mahasiswa-kkn-unimal-kembangkan-toga-untuk-

minuman-kesehatan.Diakses tanggal 28 Februari 2021. 


\section{Jurnal Pengabdian Kepada Masyarakat}

\section{BUGUH}

Dipublikasikan

Badan Pelaksana Kuliah Kerja Nyata

Universitas Lampung

Sekretariat Badan Pelaksana Kuliah Kerja Nyata, Universitas Lampung.

Jl. Prof. Dr. Soemantri Brojonegoro No. 1, Bandar Lampung 35145.

Meilina R, Dewi R, Nadia P. 2020. Sosialisasi pemanfaatan tanaman obat keluarga (toga) untuk meningkatkan imun tubuh di masa pandemi covid-19. Jurnal Pengabdian Masyarakat (Kesehatan), 2(2): 89-94.

Onchonga D. Omwoyo J. Nyamamba D. 2020. Assessing the prevalence of self-medication among healthcare workers before and during the 2019 SARS-CoV-2 (COVID-19) pandemic in Kenya. Saudi Pharmaceutical Journal.

Pertiwi R, Nutriawan D, Wibowo R H. 2020. Pemanfaatan tanaman obat keluarga (toga) meningkatkan imunitas tubuh sebagai pencegahan covid-19. Dharma Raflesia: Jurnal Ilmiah Pengembangan dan Penerapan IPTEKS, 18(2):110-118.

Sohrabi C, Alsafi Z, O'Neill N, Khan M, et al. 2020. World Health Organization declares global emergency: A review of the 2019 novel coronavirus (COVID-19). International journal of surgery (London, England) 76: 71-76.

Harjono, Y., Yusmaini, H., Bahar, M. 2017. Penyuluhan Pemanfaatan Tanaman Obat Keluarga Di Kampung Mekar Bakti 01/01, Desa Mekar Tangerang. JPM Ruwa Jurai. Vol (3):16-22

Hikmat, A., Zuhud, M.A.E., Siswoyo, Sandra, E., Sari, Bakti Kabupaten K.R. 2011. Revitalitas Konservasi Tumbuhan Obat Keluarga (TOGA) Guna Meningkatkan Kesehatan Dan Ekonomi Keluarga Mandiri Di Desa Contoh Lingkar Kampus IPB Darmaga Bogor. Jurnal Ilmu Pertanian Indonesia. Vol (16) :71-80.

Kementrian Kesehatan RI. 2020. Surat Edaran Pemanfaatan Obat Tradisional Untuk Pemeliharaan Kesehatan, Pencegahan Penyakit, Dan Perawatan Kesehatan

Permatasari, P., Hardy, R.F. 2019. Pemberdayaan Ibu Rumah Tangga Di Kelurahan Cinere Dalam Penanaman Dan Pemanfaatan Tanaman Obat Keluarga. Jurnal Bakti Masyarakat Indonesia. Vol (2):129-134.

Wahyono, Edi. 2021. "Update Lengkap Data Kasus COVID-19 di RI 3 Mei 2021”. dikutip dari https://news.detik.com/berita/d-5554774/update-lengkap-data-kasus-covid-19-di-ri-2-mei2021.Diakses tanggal 4 Mei 2021.

Maharani, Tsarina. 2021. "Update Bertambah 12.191, Kini Ada 977.474 Kasus Covid-19 di Indonesia". dikutip dari https://nasional.kompas.com/read/2021/01/23/15232411/update-bertambah-12191-kiniada-977474-kasus-covid-19-di-indonesia?page=all. Diakses tanggal 4 Mei 2021. 